\title{
Study on the Types of Public Administrative Participation in Contemporary China
}

\author{
Ma Qiongli \\ School of Finance and Public Administration, Yunnan University of Finance and Economics \\ Kunming, Yunnan, China \\ 1040086919@qq.com
}

\begin{abstract}
Based on the type of public administrative participation, the thesis studies the public administrative participation in China. Based on the research background, this thesis summarizes the specific fields and types of public administrative participation in China, analyzes its drawbacks, and puts forward suggestions for improving public administrative participation, including building a democratic and open administrative system, improving the system of public administrative participation, and promoting the legislation of public administrative participation.
\end{abstract}

Keywords: China, public administrative participation.

\section{INTRODUCTION}

In China, the practice of public participation in administration is closely related to the public's arousal of fundamental rights, which include the right to know, the right to participate, the right to express and the right to supervise. In the current process of public administration in China, the specific areas in which the public exercises these rights mainly include administrative legislation, administrative decision-making, administrative supervision and administrative relief. The public participation in these areas constitutes the main content of the current public administrative participation in China. It is of great significance to study the types and forms of public administrative participation for promoting the development of the law-based government, serviceoriented government and public governance.

\section{SPECIFIC AREAS OF PUBLIC ADMINISTRATIVE PARTICIPATION}

\subsection{Public administrative participation in the field of administrative legislation}

In administrative legislation in China, public administrative participation is embodied in the introduction of citizen participation mechanism in the process of administrative legislation, specifically in legislative hearings, legislative auditing, soliciting opinions from the public, etc. The Constitution of China clearly stipulates that "all the powers of the People's
Republic of China belong to the people, and the people administrate state affairs, economic and cultural undertakings and social affairs through various channels and forms in accordance with the provisions of the law." It shows that citizens have the right to participate in administrative legislation. Citizen participation in administrative legislation is the earliest form of public participation [1]. In the $1980 \mathrm{~s}$, relevant departments solicited experts' opinions and held expert symposiums when formulating laws and regulations. In recent years, the government has also solicited opinions of all walks of life in various ways, such as website, We Chat official account, questionnaire, and seminars, demonstration sessions and expert consultation sessions. Furthermore, the "Regulations on the Procedure for the Formulation of Administrative Regulations" and the "Rules on the Procedure For The Formulation Of Regulations", which came into effect on January 1, 2002, have made more detailed provisions on the public participation in administrative legislation in the form of administrative regulations.

\subsection{Public administrative participation in the field of administrative decision-making}

In the field of administrative decision-making in China, the administration with the characteristics of public participation originated in the 1990s, and its initial manifestation was mainly the administrative hearing. This is the first time that the Chinese government has introduced public participation into the decision-making 
discussion concerning the public interest by using the discretion, and has carried out exchanges, discussions and consultations with stakeholders on the decisionmaking matters. Since then, due to the increasingly obvious impact of government behaviours on the public interest, the public demand for effective political participation is also growing, and the government faces the increasing pressure from this aspect in the administrative process. Besides, due to the needs of the government reform, various forms of public administrative participation practice continue to develop. "Administrative Punishment Law", "Price Law", "Administrative License Law", etc. of China stipulate the hearing system.

\subsection{Public administrative participation in the field of administrative relief}

The public participation in administrative relief in China is one of the main content of public administrative participation, and it is a post rights protection mode for the public. In recent years, public administrative participation in administrative reconsideration, administrative compensation, letters and visits, personnel dispute arbitration, etc. has been growing rapidly, especially in administrative compensation, letters and visits and other related cases. On the one hand, due to the widened and unblocked administrative relief channels provided by the government, as well as the diversified relief ways, the general public can get the help and support from the government in many aspects [2]. On the other hand, the public has raised their awareness of safeguarding rights, they fully realize that they enjoy fundamental rights during interactions with the government, i.e. the right to know, the right to report, the right to defend and the right to hear, the right to participate, the information right and the right to express, and they also know how to exercise these fundamental rights to discover problems in government behaviours and effectively protect their legitimate rights and interests.

\subsection{Public participation in the field of administrative supervision}

In the administrative supervision system in China, the supervision of the people is a main form of the external supervision of the state administrative organs, which is the most common, direct and effective supervision subject. In recent years, with the government has given more attention to the supervision of the public. Especially in the new media era represented by the Internet, the online public opinion plays an important role in supervising the governmental operation, correcting the power anomie, disclosing corruption, etc. In the Internet space, the public creates the momentum and atmosphere of supervision through the informal channels such as the online public opinion, and then the topic for discussion concerning the supervision will be promoted to be involved in the formal decision-making of the government which will attach importance to the topic. This operation mode has been paid more and more attention to by the government.

\section{SPECIFIC TYPES FOR PUBLIC ADMINISTRATIVE PARTICIPATION}

\subsection{Decision-making participation}

Decision-making participation refers to the introduction of citizen participation mechanism by the government in the process of public decision-making to discuss important issues concerning formulating public policies, laws and regulations. The decision-making participation should be realized through the institutional design and arrangement of the government, generally in the form of consultation. At present, the application of decision-making participation in China is not wide, which is favoured by the governments of coastal areas instead of the counterparts in inland areas. This is mainly because of the generally high level of civic cultural education, the strong sense of administrative participation, and the relatively high benign interaction between the government and the public in the developed coastal areas.

\subsection{Hearing participation}

Hearing participation refers to the process that the government absorbs the public to listen to the decisionmaking process by holding various hearings, which is the most widespread participation adopted by local governments in China. The hearing is mainly about the government's public policies closely related to the public social life or the government's administrative measures to resolve various social conflicts, which embodies the principles of open government affairs, citizen participation and multi-party consultation [3]. This kind of hearing is actually the communication and consultation between the government and the social citizens, and it is often about specific policies or decisions. In practice, administrative decision-making hearing, price hearing, etc. belong to this category.

\subsection{Consultative participation}

Consultative participation is a form of consultation in which the government consults with the public to understand the demands for social interests and solve public problems. Advisory participation often involves long-term and big issues, such as the thinking of economic development, the arrangement of public finance, the improvement of social security, and the development of community culture. For the government, it is not only to understand the social situation and public opinion, but also to gather people's wisdom; for the citizens, it is not only the orderly participation, but also 
the expression of interests and opinions. In our country, government websites, online politics, democratic communication meetings, etc. belong to this kind of participation form and are widely used.

\subsection{Coordinated participation}

Coordinated participation refers to the form of public participation in which the government resolves the contradiction between the government and the public, or between the public and individuals through dialogue and negotiation. Such participation does not involve public decision-making or public opinion expression, but is used for the coordination of interest contradictions. In the coordination participation, the main subjects of both parties are the government and the public, or the government acts as the intermediary to mediate the contradictions between individual citizens. Its organizational form and operation mode are not institutionalized or fixed, and most of them are employed to solve specific problems [4]. Coordinated participation is a kind of effective form to eliminate all kinds of barriers caused by information jam and asymmetry through face-to-face communication of information, interests and opinions, so as to resolve interest contradictions and conflicts under the principle of mutual benefit and win-win.

\section{PROBIEMS IN CHINESE PUBLIC ADMINISTRATIVE PARTICIPATION}

\subsection{The development of public administrative participation lags behind}

Compared with other countries that have a strong democratic atmosphere and a long history of autonomy, the practice of public administrative participation in China had its inception nearly one hundred years later. The public administrative participation in China is immature due to the lack of strong institutional support in the specific practical operation process. The public fails to participate orderly in accordance with the institutional regulations, and the order of participation is also quite chaotic. The public's ability to participate in and discuss politics is weak, and the ability of autonomy is insufficient, so the public is unable to provide good constructive suggestions for decision-making.

\subsection{The channel of public administrative participation is singular}

Although the forms of public administrative participation in China are diversified in general, the ways and channels that the government provides for the public to participate are still inadequate. Especially at the level of city, county and township, the ways and channels that the government provides for the public to participate in the administration of public administrative affairs and administrative decision-making are very singular, and some areas even exclude the public from participating. No public participation is involved in the major decisionmaking process.

\subsection{The intensity of public administrative participation is weak}

Compared with developed countries, the intensity of public administrative participation in China is relatively weak. Some local governments provide the public with the opportunity to participate in the administrative decision-making and public affairs administration. Although the public has participated in the administrative process, their influence on it is very weak. Public participation is only a means for administrative organs to publicize the established policies to the public and obtain public support, rather than actually soliciting public opinions as the decision-making ground.

\section{WAYS TO PROMOTE PUBLIC ADMINISTRATIVE PARTICIPATION}

\subsection{Build a democratic and open administrative system}

The government should form a multiple governance structure, and the government departments at all levels should complement each other's jurisdiction according to the principle of decentralization and autonomy, and achieve multiple centre governance based on cooperation and competitions. In the process of administration, in addition to administrative officials, the participation of the public is also necessary [5]. The main task of officials is to provide citizens with appropriate public areas, so that citizens can take actions of self-construction. In order to carry out democratic communication and dialogues, the government must adjust and change its institution, promote decentralization of power, institutional streamlining for reasonable functions, so as to meet democratic requirements of law-based administration and the open requirements of the public for the government.

\subsection{Improve the system of public administrative participation}

The system of public administrative participation can be divided into three parts: basic system, process rules and systems and accountability system. To improve the system of public administrative participation, there is a need to guarantee the right of public participation and the publicity of government information from the fundamental system, the procedural justice of public participation from the process rules and systems, and clearly to set subjects of government responsibility and the way of claiming responsibilities in the accountability system. 


\subsection{Promote the legalization of public administrative participation}

The key factor to promote legislation lies in the distribution and check of power. The core of the governmental system is power. People's different understanding of power is not only a reflection of the past power setting path, but also a conceptual form of the continuous evolution of power path [6]. When the government realizes the important role of law in restricting power, it will inevitably promote the reform of law-based power check. In the process of legalization, the distribution of power means that power is no longer concentrated in a certain centre, and a multi-centre power pattern is formed. Only by forming a power system pattern of democratic decentralization, can we find a solution to the predicament that rights are too concentrated in the high-level politics, and then we can realize effective check of power.

\subsection{Further enrich the types of public administrative participation}

Although the Constitution gives the public the full right of administrative participation, but in reality, the types of public administrative participation are still relatively few. In China, the practice of public participation in administration is closely related to the awakening of the public's awareness of basic rights, including the public's right to know, participation, expression and supervision. In China's current public administration, the public should be fully involved in the fields of administrative legislation, administrative decision-making, administrative supervision and administrative relief. In recent years, general secretary Xi Jinping has made important strategic plans for administration according to law, and China has accelerated the process of administration according to law.

\section{CONCLUSIONS}

Since the reform and opening up, the specific areas of public administrative participation have been greatly expanded, the specific types of public administrative participation have been greatly increased, and the specific forms of public administrative participation have been continuously diversified. However, the effectiveness of public administrative participation is still weak, which needs to be further improved in an orderly manner.

\section{ACKNOWLEDGMENTS}

Thanks for Yunnan University of Finance and Economics for supporting this research.

\section{REFERENCES}

[1] John M.Bryson, Kathryn S.Quick .Designing Public Participation Processes[J], Public Administration Review, 2013, (1-2).

[2] John S·Dryzek.Foundations and Frontiers of Deliberative Governance[M].New York: Oxford University Press, 2010.

[3] Owen.Hughes.Public Management and Administration [M]. Palgrave acmillan , 2012.

[4] Angela M. Evans, Adriana Campos.Open Government Initiatives: Challenges of Citizen Participation [J].Journal of Policy Analysis and Management, 2013, (1).

[5] John M.Bryson, Kathryn S.Quick .Designing Public Participation Processes [J] Public Administration Review, 2013, (1-2).

[6] Hua Xu. Information Technology, Public Administration, and Citizen Participation: The Impacts of E-Government on Political and Administrative Processes[J], Public Administration Review,2012(6) 